\title{
Traditional and digital genres - problems and prospects of research
}

\author{
${ }^{1}$ T. L. Poliakova, ${ }^{2}$ V. V. Samarina \\ ${ }^{1}$ Kharkiv Petro Vasylenko National Technical University of Agriculture \\ ${ }^{2}$ Kharkiv National Technical University "Kharkiv Polytechnic Institute" \\ Corresponding author. E-mail: tatyanaji@mail.ru
}

Paper received 31.01.19; Accepted for publication 05.02.19.

https://doi.org/10.31174/SEND-Ph2019-191VII57-09

\begin{abstract}
The article focuses on the theoretical issues of studying the genre system of the language. The problems of choosing a term for typical forms of literary works (genres); a term for a crop of speech acts (speech genres) as well as terms for texts in Internetcommunication (digital genres and Internet-genres) are analyzed. The issues of the development of digital genres classifications, based on different criteria, are considered. The most common of these criteria are the concept of the author and the addressee, the theme and purpose of the statement, the place and time of communication, the linguistic representation of the genre, etc. One of the most convenient classifications of digital genres is the one based on the criterion of technology influence.
\end{abstract}

Keywords: genre system, literary genres, speech genres, digital genres, classification parameters.

Introduction. Linguistics of the end of the $20^{\text {th }}-$ beginning of the $21^{\text {st }}$ century is gradually changing to linguistics which is open to external influence, freely integrating with other sciences. Society is changing and these changes touch all spheres of our life, including literature, language, and communication. New linguistic directions are emerging, bringing with them new scientific paradigms.

The sphere of the theory of genres did not stand aside. The problem of studying the genre system of the language - traditional literary genres, speech genres, digital genres is one of the most relevant nowadays.

Theoretical background. As studies show, scientists are interested in both general theoretical issues of studying the genre system and the issues of speech genres theory: genres and genre forms typology; the connection of genres with language, culture, linguistic world view; linguistic identity; mass media; comparative study of speech genres; analysis of individual genres, as well as the study of digital genres that have emerged due to the development of information technology.

The term genre is derived from the Latin word genus and originates in classical philosophy, where it was used in the field of classification. According to the electronic version of the Encyclopedia Britannica, the genre is defined as "... a distinctive type or category of literary composition, such as the epic, tragedy, comedy, novel, and short story" [18].

The modern stage of the genre system study, the relation of traditional literary genres and speech genres originates in the middle of the $20^{\text {th }}$ century. The article of M. M. Bakhtin, a Russian philosopher and literary critic, "The problem of speech genres" (1953) is believed to be the most important theoretical prerequisite for studying genres in linguistics.

As for digital genres, their appearance is stipulated by the rapid development of Internet technologies, which led to the emergence of a new form of communicationcomputer-mediated or Internet-communication. Internetcommunication, as well as the language serving the new type of communication, became the subject of research of Internet-linguistics, and the new system of multimedia genres is the subject of the analysis of one of the fields of Internet-linguistics - digital genre study.

As the analysis showed, when studying both traditional literary genres and speech genres, as well as digital genres, scientists face a number of similar problems. The term genre itself often causes discussion and ambiguity. The fact that this term is actively used in a number of areas - literature, stylistics, discourse analysis, sociolinguistics, linguopragmatics, text linguistics, Internetlinguistics, etc., leads to the polysemanticity of its use. In addition, the complexity of the genre linguistic study is connected with their diversity and variability [5, p. 77]. Thus, linguists face a number of issues that require detailed study - the selection of parameters for analyzing genres, the establishment of system relations between these parameters, creation of genres classifications based on these parameters, formation of terminological apparatus in this area, etc.

Thus, the relevance of the work is stipulated by the fact that the areas of concern of the genre theory are quite complex and diverse and the nature of genres, and digital genres in particular, has not been sufficiently studied and requires further research.

The purpose of the work is to analyze the main issues of the theory of genres - the choice of a term for a specific type of texts; definitions of the concepts of genre, speech genre, digital genre; determination of general criteria for identifying digital genres, their classification.

Results and discussion. According to V. E. Chernyavskaya, the term Textsorte is often used to determine a certain type of text and it means a model, a scheme for creating and perceiving similar texts. However, this term is more often applied to non-literary, specialized texts. The term Genre is rather used for typical forms of literary works, and the terms Genre and Texttype are usually used to designate a sample, a form of the organization of the type of text [11, p. 57-62].

According to M. M. Bakhtin, the most common term for a relatively stable type of utterance [2, p. 237] is genre. Most commonly genres are defined as certain types of statements in a particular discourse [8]. In the light of the textual approach, genre is defined as a culturally and historically shaped conventionalized method of linguistic communication; a sample of text organization. This term also means a set of texts in which a certain sample is actualized [3, p. 104].

So, a genre, or rather a literary genre, is a historically emerging type of any literary work, for example, a novel, a monograph, a reportage, etc. Traditionally, literary genres are mainly types of works of art, although each epoch 
has its own system of genres in each sphere of spiritual activity and communication $[9$, p. 56].

In the XXth century along with the traditional notion of the literary genre, the notion of a speech genre emerged. The question of the relationship still remains unresolved. Speech genres are relatively stable thematic, compositional and stylistic types of texts. They are characterized by the following basic properties: they are objective in relation to an individual and are normative; they are historical, created by people in a certain era in accordance with specific conditions of social life; they are characterized by a special evaluative attitude to reality; they perform the function of integration of individuals into society; they are diverse and heterogeneous; they are a support for creativity [9, p. 352].

The main distinction of speech genres from traditional literary genres is the fact that speech genre is not just a type of single-type works of literature, but a replica, a whole statement in a dialogue and speech genre is considered as a fact of social interaction of people, as interaction of speech positions. One of the determining features of the speech genre is its dialogics principle [9, p. 53]. The characteristic features of a speech genre are the communicative situation, expression, expressive intonation, volume, the concept of the addressee [2, p. 258-270, 275279, 305].

In the framework of the communicative approach, speech genres are defined as typical models of speech behavior in repetitive communicative situations which are characteristic for certain spheres of human activity $[1, \mathrm{p}$. 34]; as a verbal and symbolic design of typical situations of social interaction of people [7, p. 104].

In the English linguistic tradition there is a large number of different interpretations of speech genres: a classifying statement, which is characterized by the presence of similar content and form, where the content relates to the subject matter of the discussion and the form - to the physical and linguistic features [21, p. 238]; a type of communicative events that have common communicative goals and a similar structure, stylistic features, content and audience for which this type is intended [22, p. 58], etc.

In the sphere of Internet-communication, the term gen$r e$ was first introduced into the field of information system research in the early 1990 s by J. Yates and W. J. Orlikowski.

A large variety of texts and styles, functioning in the Internet, has become one of the main characteristics of this new communicative environment. Many of them are characterized by specific features that manifest themselves at all linguistic levels.

Currently, many researchers $[1 ; 12]$ are engaged in the description of the language in the texts of specific Internet services (e-mail, chat, web page, etc.), emphasizing some of their characteristics. However, such a variety of texts in the Internet and a variety of approaches to their description extremely complicates the understanding of their differences from each other. All this leads to the necessity to choose a single term for each group of communications, as well as to develop the criteria on the basis of which this grouping takes place.

D. Crystal, for example, along with the use of the term genre, uses the term broad Internet-using situations [15].
Such terms as speech community, register, text, discourse type [16, p. 6], communicative practice [20], form of communication [17], format [10], etc. are also used.

The terms proposed, however, do not reveal the nature of individual groups of texts, and it is the term genre, being widely used in traditional linguistics, that does not cause ambiguous understanding and points to the linguistic component of the texts under study and is also the most appropriate when describing the linguistic features of the text of Internet-communication.

There are a lot of definitions of digital genres, for example it is defined as a stable type of text, a form that specific manifestations of speech activity in the field of computer-mediated communication take [12, p. 20].

Researchers have attempted to classify digital genres for a long time, and here scholars face a rather complex problem, as in the sociocommunicative space of the Internet, digital genres appear, form, change, and sometimes disappear much faster than in real communication [4, $\mathrm{p}$. 11]. As a result, we can find a wide variety of different classifications of these genres in foreign and domestic linguistic literature, based both on the foundations of classifications of traditional genres and on new ones [5, p. 275].

So, as the analysis showed, classifications of digital genres are commonly based on certain genre-forming characteristics which cover: statement topic, communicative purpose, the concept of the author, the concept of the addressee, linguistic representation of the genre, the sphere of communication, synchronous / asynchronous mode of communication, dialogue / polylogue, composition $[1$, p. 35-36].

In the foreign literature there are also various parameters for describing digital genres: communicative purpose, structure of functioning [19, p. 17; 22; 23, p. 63], rhetorical strategies (verbal and visual) [22], hypertext, content $[19$, p. $17 ; 23$, p. 63], concepts of the author and addressee, temporal restrictions on the genre existence, local parameters of the genre existence [23, p. 63], functionality $[19$, p. 17].

Thus, taking into account all mentioned above, the complex model of a digital genre presented by L. Yu. Schipitsina is the most interesting one. It covers the following parameters: media parameters (genre design, multimedia, hypertextuality, interactivity, synchronicity, the number and explication of communicants); pragmatic parameters characterizing the situation of the genre use (communicative purpose, type of author, type of addressee, place, time); structural and semantic parameters (the description of the content of the text of a particular genre and structural elements in which it is embodied); linguistic parameters (specific linguistic means used in the creation of texts of various genres [13, p. 27-63].

The variety of criteria for classifying digital genres as well as the difficulty in determining common parameters for describing all genres in Internet-communication lead to a variety of classifications of the genres in the new communicative environment.

The most common classification of digital genres is their division into genres that are originally web based (chats) and genres borrowed from other spheres of communication (abstracts of scientific) [1, p.34]. 
Depending on the type of discourse, digital genres are divided into: personal discourse (personal chats); political discourse (political web pages); legal discourse (legal forums); business discourse (online stores); advertising discourse (web banners); mass information discourse (web pages of online media and news agencies); pedagogical discourse (academic web pages of universities) [14, p. 209].

Basing on the fact that a genre represents a specific type of utterance within a certain discourse, there is a classification of digital genres based on the structure and composition of its text. Genres singled out on the basis of these criteria are defined as discourse-forming genres (email, chat, forum, blog, etc.). There are also discourseacquired genres (flame, message, spam), which are determined on the basis of the intentional variety of text statements [7, p. 11].

Depending on the communicative functions of Internet-communication, digital genres are divided into: informative genres (web pages of news agencies, online encyclopedias); directive genres (web advertising, online stores); communicative genres (chats, newsgroups, forums); presentation genres (personal web pages, weblogs); aesthetic genres (network affair); entertainment genres (multiplayer worlds and games) [15, p. 3].

However, it is considered that it is most convenient to classify digital genres using the criterion of "technology influence", on the basis of which they distinguish: ordinary paper genres that have not undergone a significant change in the network (scientific articles in $p d f$ format); digital or virtual genres that emerged due to the technical capabilities of the Internet (chats or instant messaging), as well as hybrid genres that either have changed significantly under the influence of Internet technologies (blogging) or mutated into other forms (multi-user worlds like Muds or Moors [4, p. 11-12].

Based on the technological criterion, digital genres can also be classified into: genres of the first web (web 1.0), the content of which is created by professionals of the web community and is practically unchangeable. The influence of the technological factor in this case is minimal (pdf, WinDjView texts, etc.); genres of the second web (web 2.0), the content of which can be created and changed by ordinary users whose number is unlimited. The impact of Internet technologies in these genres is quite high (social networks, blogs, etc.); genres of the third web (web 3.0), implying that both ordinary users and professionals take part in creating the content. The impact of Internet technologies is maximum (Online Favorites Service).

Thus, we can conclude that the problem areas of the modern theory of genres are extremely multifaceted, diverse, and are of great interest to modern scholars.

So, the basic terms for denoting a certain type of text cover: text type which implies a model for creating similar texts and genre - a typical literary work. In addition, in modern linguistics there is also a concept of speech genre, implying a relatively stable type of utterance.

The rapid development of information technology, Internet-communication has led to the emergence of a large number of texts and styles that operate in a new communication environment and which require a single term for designation. Among the variety of the terms, it is the term digital genre that is the most popular one and which is defined as settled patterns type of text adopted by specific manifestations of speech activity in the computermediated communications [13, p. 20].

The main parameters for describing digital genres cover the concept of the author, the concept of the addressee, the purpose, time and place of communication, event content, implementation in the hypertext structure, the use of a hypertext visual and audio component, linguistic parameters, etc.

There exist a large number of classifications of digital genres, based on various criteria such as the type of discourse, the subject matter, structure and composition of its text, Internet-communication functions; the development of Internet technologies of Web 2.0; the technological criterion, etc.

Thus, the problems of the modern theory of genres are extremely complex, multifaceted and of great scientific interest for modern linguistics, because though many works by Ukrainian and foreign researchers are devoted to the issues of both traditional and digital genre studying, there is still a lot of unexplored and controversial. It concerns working out common terminology in this sphere, finding general criteria to select genres, making their classifications, describing linguistic characteristics of individual genres. All these factors make us critically generalize the existing achievements in this field and determine the prospects for further research.

\section{REFERENCES}

1. Асмус Н. Г. Лингвистические особенности виртуального коммуникативного пространства. Дис. ... канд. филол. наук: 10.02.19. Челябинск, 2005. $266 \mathrm{c}$.

2. Бахтин М. М. Эстетика словесного творчества. М.: Искусство, 1979. 424 с.

3. Гайда С. Жанры разговорных высказываний // Жанры речи: Сб. науч. статей. Саратов: Изд-во ГосУНЦ «Колледж», 1999. С. 103-111.

4. Горошко Е. И. «Чирикающий» жанр 2.0 Твиттер, или что нового появилось в виртуальном жанроведении // Вестник Тверского государственного университета. Серия «Филология». 2011. № 3. С. 11-20.

5. Дементьев В. В. Теория речевых жанров. М.: Знак, 2010. $600 \mathrm{c}$.

6. Лутовинова О. В. Лингвокультурологические характеристики виртуального дискурса: монография. Волгоград: Изд-во ВГПУ «Перемена», 2009. 477 с.

7. Седов К. Ф. Дискурс и личность: Эволюция коммуникативной компетенции. М.: Лабиринт, 2004. 320 с.

8. Силантьев И. В. Текст в системе дискурсных взаимодействий // Критика и семиотика. 2004. Вып.7. С. 98-123.

9. Стилистический энциклопедический словарь русского языка / [под ред. М. Н. Кожиной]. М.: Флинта, Наука, 2006. $696 \mathrm{c}$.

10. Усачева О. Ю. Диалогическая речь в среде Интернет // Язык средств массовой информации как объект междисциплинарного исследования: Материалы 2-й Междунар. конф. (Москва, филологический факультет МГУ имени М. В. Ломоносова, 14-16 февраля 2008 г. М.: МАКС Пресс, 2008. С. 408-410.

11. Чернявская В. Е. Лингвистика текста: поликодовость, интертекстуальность, интердискурсивность. Учебное пособие. М.: Книжный дом «ЛИБРОКОМ», 2009. 248 с. 
12. Щипицина Л. Ю. Жанры компьютерно-опосредованной коммуникации : монография. Архангельск: Поморский университет, 2009. $238 \mathrm{c.}$

13. Щипицина Л. Ю. Компьютерно-опосредованная коммуникация. Лингвистический аспект анализа: Монография. М.: КРАСАНД, 2010. 296 с.

14. Щипицина Л. Ю. Комплексная характеристика жанра компьютерно-опосредованной коммуникации (на примере веб-страниц новостных агентств) [Электронный ресурс]. Режим доступа к журн. http://www.pags.ru/science/conferences/EConference/Shipitina.doc

15. Crystal D. Language and the Internet. Cambridge: Cambridge University Press, 2004. 272 p.

16. Crystal D. Investigating English style. London: Longman, 1969. $264 \mathrm{p}$.

17. Durscheid Ch. Medien, Kommunikationsformen, kommunikative Gattungen [Электронный pecypc]// Linguistik online. 2005. Nr. 22/1. Режим доступа к журн.: http: //www.linguistik online.de/22_05/durscheid.html.
18. Genre. Encyclopedia Britannica. Режим доступа к журн.: https://www.britannica.com/search?query=genre

19. Ihlström C. The Evolution of a New(s) Genre. Doctoral Dissertation. School of Information Science, Computer and Electronic Engineering, Halmstad University; Department of Informatics, Göteborg University. Gothenburg Studies in Informatics, 2004. $164 \mathrm{p}$.

20. Runkehl J., Schlobinski P., Siever T. Sprache und Kommunikation im Internet: Überblick und Analysen. Opladen; Wiesbaden: Westdt. Verl., 1998. 240 S.

21. Shepherd M., Watters C., Kennedy A. Cybergenre: Automatic identification of Home pages on the Web // Journal of Web Engineering. Dalhousie University, Halifax: Rinton Press, 2004. Vol. 3. No.3, No.4. P. 236-251.

22. Swales J. M. Genre Analysis - English in academic and research settings. Cambridge: Cambridge University Press, 1990. $274 \mathrm{p}$.

23. Yates J., Orlikowski W. J. Genre Systems : Structuring Interaction through Communicative Norms // Journal of Business Communication. London: SAGE Publications, 2002. Vol. 39. No 1. P. 13-35.

\section{REFERENCES}

1. Asmus N. G. Linguistic features of virtual communicative space. Cand. philol. sci. diss.]. Chelyabinsk, 2005. 266 p.

2. Bakhtin M. M. Aesthetics of verbal art. Moscow: Iskusstvo Publ., 1979. 424 p.

3. Gaida S. Conversational genres // Speech genres: collection of scientific works. Saratov: Kolledzh Publ., 1990. P. 103-111.

4. Goroshko E. I. "Twittering" genre 2.0 Twitter or what is new in digital genre theory // Bulletin of Tver state university, 2011. No. 3. P. 11-20.

5. Dementyev V. V. Theory of Speech Genres. Moscow: Znak, 2010. $600 \mathrm{p}$.

6. Lutovinova O. V. Linguistic and cultural characteristics of virtual discourse: monograph. Volgograd: Peremena Publ., 2009. $477 \mathrm{p}$.

7. Sedov K. F. Discourse and personality: the evolution of communicative competence. Moscow: Labyrinth Publ., 2004. 320 $\mathrm{p}$.

8. Silantyev I. V. Text in the system of discourse interactions // Critique and semiotics. 2004. Issue 7. P. 98-123.

9. Stylistic encyclopedic dictionary of the Russian language Ed. by M. N. Kozhina. Moscow: Flinta, Nauka, Publ., 2006. 696 $\mathrm{p}$
10. Usacheva O. Yu. Dialogic speech in the Internet environment // Language of the media as an object of interdisciplinary research: Materials of the 2nd Intern. conf. (Moscow, Faculty of Philology, Moscow State University named after M. V. Lomonosov, February 14-16, 2008. Moscow: MAKS Press Publ., 2008. P. 408-410.

11. Chernyavskaya V. E. Text linguistics: polycodularity, intertextuality, interdiscoursiveness. Study guide. Moscow: "LIBROCOM", 2009. 248 p.

12. Shchipitsina L. Yu. Genres of computer-mediated communication: monograph. Arkhangelsk: Pomor state university, Publ., 2009. 238 p.

13. Shchipitsina L. Yu. Computer-mediated communication. Linguistic aspect of the analysis: monograph. Moscow: KRASAND, Publ., 2010. 296 p.

14. Shchipitsina L. Yu. Comprehensive characteristics of the genre of computer-mediated communication (on the example of web pages of news agencies). Available at: http://www.pags.ru/science/conferences/E-

Conference/Shipitina.doc. 